\title{
Model of Knowledge for Students Prospective
}

\author{
Nirwana Anas ${ }^{1}$, Riris Nurkholidah Rambe ${ }^{2}$ \\ \{nirwana.anas46@gmail.com ${ }^{1 *}$, ririsnurkholidah@uinsu.ac.id² \\ ${ }^{1,2}$ Doctoral Program Student, Universitas Negeri Medan, Indonesia \\ *nirwana.anas46@gmail.com
}

\begin{abstract}
Various attempts have been made to make teachers a profession that is on par with other professions in the world. LPTK as a teacher producing institution is the party responsible for preparing teacher candidates. This article aims to introduce a learning model that can improve the professionalism of prospective teacher students. The learning model developed refers to the criteria of the model developed by Joyce \& Weil. AJARI learning model is a learning model that in learning has natural characteristics, describe / articulation, reflection and my ideas. In this learning model students are expected to experience the experience of a scientist at the same time get the opportunity to design learning according to their creative ideas. Through this learning model, it is expected to be a unique learning model for prospective teacher students.
\end{abstract}

Keywords: learning model, prospective teacher students

\section{Introduction}

History records, in 1875 in America requires an Elementary School teacher to have 20 competencies, namely: writing arithmetic, mental arithmetic, writing grammar, grammatical speaking, geography, United States history, theory and practice of teaching, algebra, sports, physics, legislation American and California invitations, California school law, handwriting, biology, composition, reading, defining (word and vocabulary analysis), vocal music and industrial images ${ }^{i}$. Based on this information it appears that so many competencies that must be possessed by an Elementary School teacher. Through this set of knowledge, elementary school teachers are expected to be able to teach well. But there is no information on how a set of knowledge is utilized in an effort to educate the students they teach.

In 1986 and 1987 Lee Shulman studied the standard of knowledge that must be possessed by a teacher because he felt there was "something missing" and he tried to find "something different" from teacher education. Since then, Shulman has fought for the equality of the teaching profession so that he is recognized as equal to other professions such as the doctor, lawyer and other professions. The teacher must have specific knowledge that distinguishes it from other professions so that with this knowledge not everyone can become a teacher $[1,2]$.

Policymakers and teacher education institutions at that time required teachers to have three competencies, namely: basic skills, content knowledge, and general pedagogical skills. Basic skills are the ability to read, write, spell, calculate, and solve arithmetic problems. Content knowledge is the ability related to mastery of material related to subjects, such as mathematics, language, Natural Sciences or other subjects. Whereas, general pedagogic skills 
are skills that must be possessed by someone who wants to be a teacher. In other languages, general pedagogical skills can be interpreted as the science of educating.

The scientist who has explored the basic knowledge of teachers is Joseph Schwab [1], he discusses the structure of knowledge related to the mastery of the knowledge of teacher subjects. He distinguished the structure of subject knowledge into substantive and syntactic structures. The substantive structure is a concept that forms the basis of content, whereas the syntactic structure is a structure that is related to scientific acquisition procedures.

Shulman identified seven components of knowledge-base that teachers must have, namely: content knowledge; general pedagogical knowledge; curriculum knowledge, pedagogical content knowledge; knowledge of learners and their characteristics; knowledge of educational contexts; knowledge of educational ends purposes and values; and their philosophical and historical grounds [2]. Ball D. L, et al. [3] looked at the seven basic components of Shulman's teacher knowledge into two categories based on general knowledge and knowledge related to specific content, namely: general dimensions of teacher knowledge (general pedagogical knowledge, knowledge of learners and their characteristics, knowledge of educational contexts, knowledge of educational contexts, knowledge of educational ends, purposes, and values, and their philosophical and historical grounds) and content-specific dimensions (content knowledge, pedagogical content knowledge, curriculum knowledge). The general dimension is the knowledge that is absolutely possessed by all who bear the teaching profession. The special dimension of content is knowledge related to the specific ability of the subject teacher, which is related to the mastery of teaching material.

Based on the opinion of Ball et al. [4] the basic ability of a teacher could not be separated from the specific mastery of teacher content on subjects. He thought that a teacher might not develop a methodology of learning if teachers do not have much knowledge related to the subject matter to be taught. Teacher creativity will not develop if the mastery of the material they have is too narrow. The possibility of finding alternatives to the delivery of material is more than just the transfer of knowledge to be small. The specific mastery of content referred to by Ball is Pedagogical Content Knowledge referred to by Shulman.

There is a difference between the subject matter and teaching material. When a student learns so that students gain real knowledge he is learning course material and this process is lived as a scientist. When students learn how to teach well, students are actually learning teaching material. This process is carried out in the context of mastery of knowledge as a provision of teaching a teacher. According to Brousseau [5] based on several studies in mathematics say the following:

"A mathematician will not communicate the results of their research by the way they find, they will rearrange, give in a general form. The form of didactic practices carried out by mathematicians by placing the knowledge they have into forms that can be communicated, decontextualized (eliminating context), depersonalized (eliminating personal perspective), and de-temporal (not bound by time). Whereas the teacher takes the opposite action, namely recontextualization (providing context) and personalized (giving a personal perspective). The teacher looks for situations that can give meaning to the knowledge to be taught. When students have responded to the situation proposed by students decontextualized (eliminating the context) and depersonalized (eliminating again the personal perspective), the knowledge students have gained so that students can see that the material they understand has a universal character and that is cultural knowledge that can be reused ".

Referring to the opinion of Brousseau [5] and Ball et al. [4] about the mastery of content that must be owned by a teacher, which states learning for a prospective student-teacher is not like learning by a scientist. So the provision of knowledge for a prospective teacher-student 
needs to be done in preparation for the student when becoming a teacher. The teacher will be able to contextualize the material he masters for students to learn. Good mastery of knowledge will affect the ability to contextualize the material.

\section{Analysis and Discussion}

a. Teacher knowledge

Teachers are one of the oldest professions in the world. The teacher profession is considered noble because through teacher children can open their horizons to see the world. Minister of Research and Technology Regulation No. 55 of 2017 [6] concerning Teacher Education Standards that govern the administration of higher education in order to produce teachers as professional educators is a juridical foundation for the organization of education for prospective teachers.

Teachers are academically successful end products of education systems throughout the world, having memorized techniques, memorizing, experimenting, and solving welldeveloped problems. As such, prospective teachers tend to perform well in school and university exams, but their education does not eradicate, challenge or change strongly held ideas or wrong thoughts about science concepts.

There are two categories in the educational research paradigm, namely theory and practice. The theory prepares well, while the experience belongs to practitioners. So the competency formulation owned by the teacher is not on the same track. Based on this problem, the government prepares teachers through teacher preparation education. A good teacher is prepared through lectures at the LPTK (Educational Personnel Educational Institution). Prospective teacher students are prepared through theory so they can practice well based on the teacher's experience. Good debriefing through lectures is expected to produce professional teachers.

According to Brousseau [5] based on several studies in the field of mathematics, a scientist will not communicate the results of their research by the way they find the knowledge they have acquired, they will rearrange, give in a general form. Forms of didactic practice carried out by scientists by placing the knowledge they have into forms that can be communicated, eliminate context, eliminate personal perspective and are not bound by time. Whereas the teacher takes the opposite action, namely providing context to the knowledge to be taught and providing a personal perspective. The teacher looks for situations that can give meaning to the knowledge to be taught. When students have responded to the proposed situation, students again eliminate the context that the teacher has added and also eliminate the personal perspective. Students return the knowledge delivered by the teacher to a universal form that can be understood by everyone.

Based on the opinion above, there are differences in lecture material conducted in LPTK that are spread over courses that must be passed by prospective teacher students. As a result of lectures, a prospective student teacher has knowledge of the learning process that makes him have knowledge as a scientist. Prospective teacher students also have to teach knowledge, that is the knowledge possessed as provisions when he is a teacher.

Government Regulation No. 74 of 2008 [7] article 7 paragraph a mandates: Professional competence as referred to in paragraph (2) is the ability of the Master to master the knowledge of the fields of science, technology, and / or arts and culture that he may be professing at least covering a broad and deep mastery of subject matter in accordance with the standard content 
of the education unit program, subjects, and/or groups of subjects to be supported. Based on this government regulation, to meet the qualifications as a professional teacher, the teacher must master the material based on the standard content of the education unit curriculum.

The process of forming good teachers must be prepared from the education process of prospective teachers. Prospective teacher knowledge is essential for teachers to be able to teach effectively $[8,9]$. Prospective teacher knowledge factors in mastering Subject Matter indepth also play a role in supporting learning $[1,3]$.

The National Higher Education Standards (SN Dikti) regulated in the Minister of Education and Culture Regulation 2014 is a standard unit that includes the National Education Standards, which set minimum criteria for learning at tertiary levels in tertiary institutions throughout the jurisdiction of the Unitary Republic of Indonesia. The National Education Standards include regulating graduate competency standards, learning content standards, learning process standards and learning assessment standards that are directly related to the learning process plus other standards relating to administration. Graduate Competency Standard (SKL) is a minimum criterion regarding the qualifications of graduates' abilities that includes attitudes, knowledge, and skills expressed in the formulation of learning outcomes. In the SKL it is stated that the learning achievements of graduates must refer to the description of KKNI learning outcomes (Indonesian National Qualification Framework). Learning Content Standards are minimum criteria for the level of depth and breadth of learning material, and must refer to graduate learning outcomes. Four elements of learning outcomes include attitudes and values, workability, mastery of knowledge, and authority and responsibility. Elements of learning outcomes in graduate competency standards include attitudes, knowledge, and skills.

Regulation of the Minister of Research, Technology and Higher Education of the Republic of Indonesia Number 55 the Year 2017 Concerning Teacher Education Standards Part One Competency Standards Article 7 paragraph (3) which states the formulation of learning outcomes must contain academic aspects of education and fields of science and/or expertise. Furthermore, paragraph (4) is explained further about the aspects referred to include: a) the competency of understanding students; b) educational competencies that educate; c) competency in mastering scientific fields and/or expertise; and 4) attitude and personality competencies.

In the attachment to the copy of the regulation is explained about the formulation of the Learning Achievement of Graduates of Education Undergraduate Program that contains four competencies of Teacher Education Standards. One of the four competencies is mastery of scientific fields and/or expertise. In more detail this competency is described as a) mastering the objectives, content, learning experiences, and assessments in the curriculum of the education unit; b) master the scientific concepts and methods that overshadow the substance of the field of study; c) deepening the field of study in accordance with the environment and changing times; d) mastering the integration of technology, pedagogy, scientific content of funds / or expertise, and communication; e) develop curriculum in accordance with the field of work; f) manage educational unit level curricula; g) disseminating academic work in the form of publications uploaded in reputable college pages and/or journals; and $h$ ) applying information technology knowledge and skills in the context of scientific development and implementation of the area of expertise.

b. Subject Matter Knowledge in the education of prospective teachers

Shulman [2] defines Content Knowledge in reference to the amount and organization of knowledge per se in the teacher. It is a way of thinking correctly about the knowledge that 
goes beyond knowledge of facts or concepts. Content Knowledge is also known as the Subject Matter Knowledge [2], covering the theories, principles, and concepts of certain disciplines that must be learned taught. Subject Matter Knowledge requires independent knowledge and understanding of facts and constructions, and the relationship between facts and the construction of a discipline. Teachers' Subject Matter Knowledge strengths and weaknesses have an impact on their classroom practice [10]. Compared to teachers with strong science Subject Matter Knowledge, teachers with weak Subject Matter Knowledge teach less science and choose paper and pencil exercises more often than didactic science-based inquiry.

Subject Matter Knowledge is the heart of teaching [11] and teachers must know the material being taught. Subject Matter Knowledge includes didactic schools [5,12] and Pedagogical Content Knowledge perspectives [1]. Carlsen [13] states, when teaching unfamiliar topics (showing low Subject Matter Knowledge mastery), teachers talk more often and for longer, often ask questions, and questions are at a low cognitive level. Teach is dominated by a one-way conversation is a way of overseeing the discussions. When the teacher is less familiar with the topic being taught, the teacher tends to ask more questions to control the discussion. When the teacher is more familiar with the topic, students are more engaged in conversation. Questions asked by students are not common.

Subject Matter Knowledge is basic to core teaching activities and influences teachers in making decisions about specific learning, such as designing assignments or asking questions that are meaningful for student exploration [14]. A teacher's ability to choose the right way to convey mathematical ideas depends on what Ma (1999) calls "a deep understanding of subject knowledge" (p.120), also referred to as "flexible subject understanding" [3]. Some special elements in Subject Matter Knowledge facilitate mathematics teachers to teach mathematical content more meaningfully [14].

Based on the opinions of some experts above, Subject Matter Knowledge is knowledge about the material that must be mastered by a teacher. Subject Matter Knowledge is needed by a teacher as a condition of mastery of the material to be taught to students. Subject Matter Knowledge is a prerequisite for developing Pedagogical Content Knowledge. Pedagogical Content Knowledge is a way for teachers to present subject matter to their students.

\section{c. Development of Subject Matter Knowledge Theory}

Ball, Thames, and Phelps [4] stated: "Teachers need to know the material they teach, they must recognize when their students give incorrect answers or when textbooks provide inaccurate definitions. "(P. 399). Ball et al. [4] about teacher knowledge as shown in the figure 1 the following: 


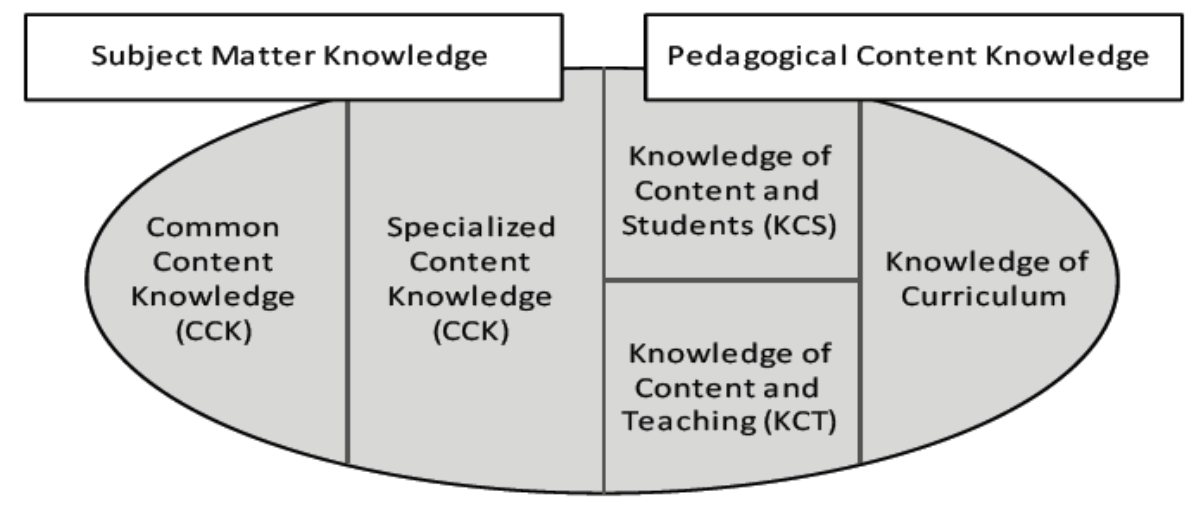

Fig 1. Teacher knowlegde by Ball et al. [4]

Subject Matter Knowledge can be broken down into Common Content Knowledge ( CCK) and Specialized Content Knowledge (SCK). CCK is a general knowledge about very basic subjects and its nature is very general. This knowledge is owned by someone who has learned a subject without special emphasis on mastery of a particular material. In contrast to CCK, SCK is special knowledge "that allows teachers to be specifically involved in teaching assignments, including how to accurately represent ideas of subjects, provide explanations for general rules and procedures, and examine and understand methods of unusual solutions to problems " [4].

Grossman [15] divides Subject Matter Knowledge into 3 categories namely: Syntactic Structures, Content, and Substantive Structure. Grossman developed the Subject Matter Knowledge Schwab [16] by adding knowledge content to the knowledge of a prospective teacher.

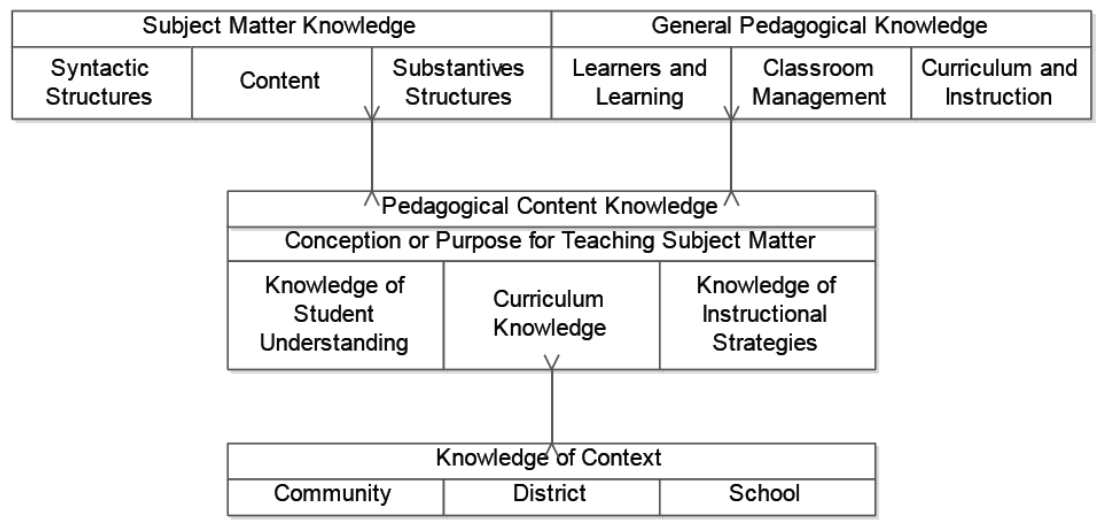

Fig 2. Teacher knowledge by Grossman

Grossman explained that Subject Matter Knowledge includes facts, concepts, rules, and relationships between concepts, rules, and relationships between concepts that are still one family in the discipline. In Subject Matter Knowledge there is certainly content that is the subject of discussion in the form of certain material relating to certain subjects. The content in 
question is related to the study material that will be taught on the subject matter. The syntactic structure is knowledge about processing facts, methods of proving and manipulating it so that it is useful in solving problems. This is seen as knowledge about how to obtain true knowledge. Substantive structures are the way a person processes information. This difference in viewpoints requires substantial knowledge in understanding a concept contained in a material. This component of substantive structures is very important because it determines whether someone is able to understand and develop material facts or not. Syntactic structures and substance structures affect as well as possible.

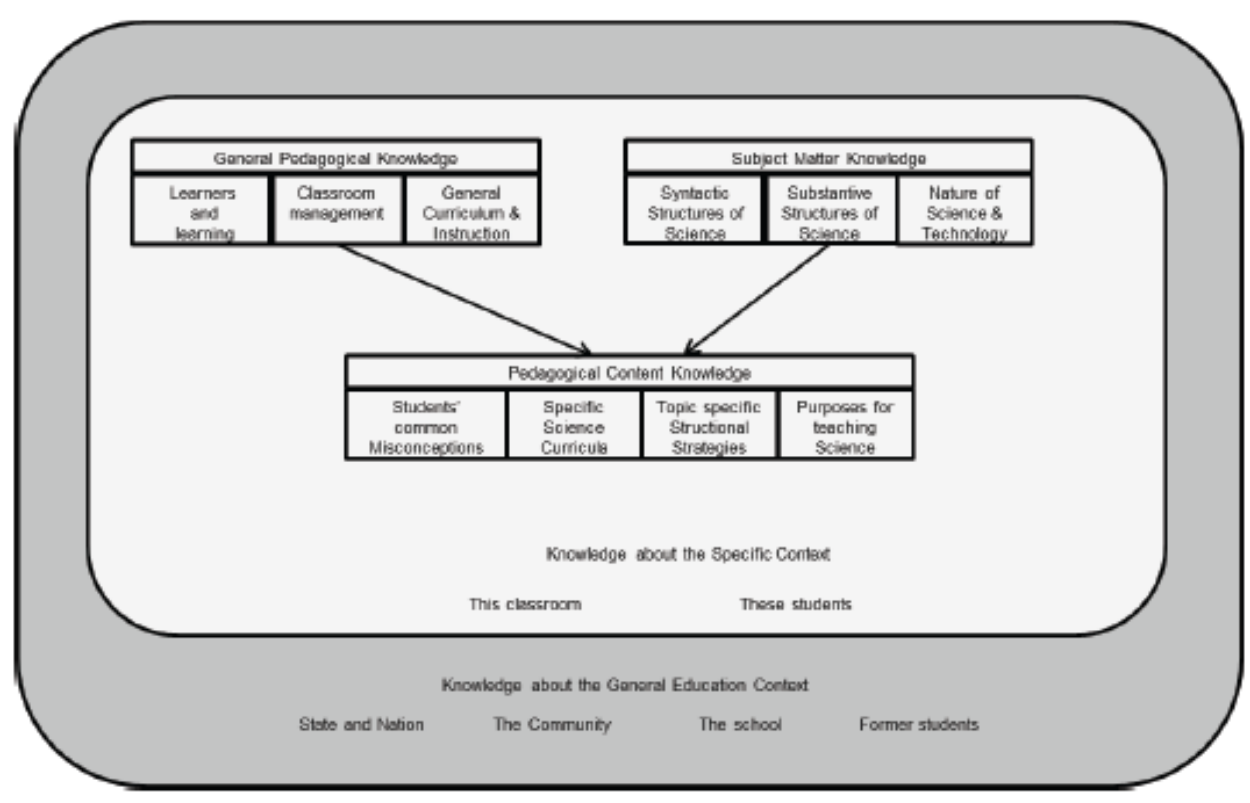

Fig 3. Teacher Knowledge by Carlsen

The Subject Matter Knowledge model developed by Carlsen [13] is 3: Syntactic structure of science, the substantive structure of science and the nature of science and technology. Subject Matter Knowledge models Carlsen different from the one developed by Grossman, if Grossman add content other than syntactic structure and substantive structure which is the way and the content subjects, Carlsen added nature of science and technology (the characteristics of science and technology) are considered Carlsen as the nature of the inherent when the process is undertaken in a content discovery effort.

John Dewey [17] in his book entitled "The Supreme Intellectual Obligation" said the importance of scientific skills and attitudes in teaching science. According to DeBoer, Paul DeHart Hurd [18] in his book entitled " Science Literacy: Its meaning for American School", defines scientific literacy as being used to explain the understanding of science and its application in social experience. DeBoer [18] defines scientific literacy as an understanding of science and its application in life. Science literacy is the ability to use scientific knowledge to identify problems and draw conclusions based on evidence in order to understand and make decisions about nature and changes made to nature through human activities [19].Based on some of the opinions above, that the orientation of learning science (science) must experience changes. 
Subject Matter Knowledge according to Schwab consists of substantive and syntactic structures, and if analyzing the scientific literacy above, it is considered necessary to make changes to the structure of knowledge. If in one knowledge, it is deemed necessary to stakes to form substantive, then it is deemed necessary to know how the application of the substantive structure formed is. The application of the knowledge formed is needed in order to ensure that the knowledge obtained can be known for its benefits in real life. Based on the opinion above, this application is called literacy.

\section{d. The aspect of Subject Matter Knowledge}

According to Schwab [16], knowledge structures include substantive and syntactic structures. The substantive structure is the variety of ways in which the scientific principles and basic principles are arranged to include the facts. The syntactic structure of knowledge is a set of ways in which truth is taught. A set of rules to determine what is legitimate to say in the disciplined domain and what is in violation. The knowledge content is defined as "concepts, principles, relationships, processes, and applications that students must know in certain academic subjects, appropriate for themselves and the organization of knowledge [20].

According to Grauer [21], Subject Matter Knowledge is not recitational knowledge (repetition of knowledge and facts). A teacher should not only rely on the knowledge he has learned while he is in school and even up to college. Beeby [22] categorizes teachers into four, namely: 1) Dame Schools, namely untrained and uneducated teachers, memorized and meaningless knowledge; 2) Formalism, teachers who are not educated but are trained. Teachers are organized, uni-dimensional, and memorized by knowledge. Teachers at this level find it difficult to keep up with curriculum changes. 3) Transition, better educated and trained, so that the learning delivered is meaningful, less tied to textbooks and syllabus; 4) Meaning, well educated and trained. Teachers at this level are able to insert meaning and understanding into their teaching, understand individual differences and use resources more productively. Based on the opinion of Grauer and Beeby, the subject matter learning must be able to shape the teacher's meaning, so that the learning experienced by students is also more meaningful.

\section{e. Learning Design Model}

Gustafron and Branch explain the model is: "a simple form of representation of a complex. The model contains the processes and functions of physical phenomena or ideas ". Next Snelbecker explained that: "the model is a concretization of the theory that aims to mediate the processes and variables contained in the theory".

According to Richey, Klein, and Tracey [23], the model is: "a representation of reality presented with a level of structure and order and the model is a simplified idea of reality". Furthermore Personal explains the model is: "something that describes a pattern of thinking". In this case, the model can be seen as an effort to concretize a theory as well as an analogy and representation of the variables contained in the theory.

The definition stated by the Association for Education Communication and Technology (AECT) that the model is: Form that is conceptually the same as the original form, the form can be physical, a verbal description, or graphic form that is the same as actually or should be, and the model is a form of imitation.

Prawiradilaga [24] explains the model can be interpreted as: "graphical display, work procedures that are organized or systematic and contain thought in the nature of a description or explanation of suggestions. Whereas Sagala explains the model is: "the conceptual framework used as a guide in carrying out activities." 
Based on the description of the concept of the model above, it can be interpreted that the model is designed to represent the real reality, even though the model itself is not the reality of the real world. In this case, the model is: (1) a description needed to help the visualization process that cannot be observed directly; (2) a system of assumptions and data used to logically and systematically describe an object or event; and (3) procedures that must be followed in carrying out an activity so that the series of activities becomes a system ".

In a component model, there are (1) components; (2) rules that connect between components so that they become one system; and (3) interactions between components into a single unit that can deliver messages. Understanding of the models is important for learning developers, as explained by Personal that: "A learning program design needs to have a good understanding of learning system design models. This is done in order to be able to implement these models to create learning programs that have effectiveness, efficiency, and attractiveness. Learning design models, usually used in the form of flowcharts or whose implementation needs to be done systematically and systematically ".

Furthermore, related to the benefits of using the model described by Seels and Glasgow, namely: (1) the model visualizes a systematic process that allows for concentration in the process undertaken; (2) the model is a tool for managing processes and projects; (3) through the model it is possible to test theories in an integrated and practical way to be applied; and (4) through the model, the tasks set by the designer become good design criteria.

Soekamto explained the benefits of the model for learning designers, namely: (1) tools for communicating between themselves and also with clients; (2) instructions on planning activities to be carried out on management; and (3) a number of prescription rules for decision-making.

\section{f. Prospective Teacher Student Knowledge Model}

The MPRA model (Model of Pedagogical Reasoning and Action) developed by Shulman [1] and Salazar [25] explains that most teaching begins with some form of "text", textbooks, scripts or other material that the teacher wants to understand or student. This collection of knowledge is contained in cycles through activities of understanding, transformation, instruction, assessment, and reflection. The process on the MPRA Model of teacher knowledge at the beginning of I and at the end of I with the act of understanding Because of its procedural nature, MPRA requires a teacher reasoning process about content for teaching that is under continuous restructuring. Their dynamics are enriched by the context in which it occurs as a result of social interaction that implies different educational activities and periods that characterize teaching practice. The MPRA model is a dynamic and cycle model of teacher reflection and action. This model seeks to embrace the teacher's knowledge about the subject matter and methodological approaches that develop in certain subjects. At each step, a series of knowledge and skills are needed. Thus, in the MPRA model, Shulman represents the steps that occur in the development of teacher professional practice, especially using certain content. Shulman's contribution was to restore the "lost paradigm" and bring to the knowledge content of teachers' specific content. However, he is bound to the pedagogical dimension. And the transformation of this content into a powerful way pedagogy is what Shulman calls knowledge pedagogical content.

Referring to the MPRA model that explains the teacher knowledge model that represents the steps that occur in the development of teacher professional practice, then the knowledge model for student-teacher candidates is developed. there are differences in learning orientations between teacher and student-teacher candidates. For in-service training teachers, learning outcomes can immediately be applied, whereas for prospective teacher students (pre- 
service training) tend to learn to have the abilities that will be needed when becoming a teacher. Based on these different paradigms, the model is developed as presented in the figure 4 the following:

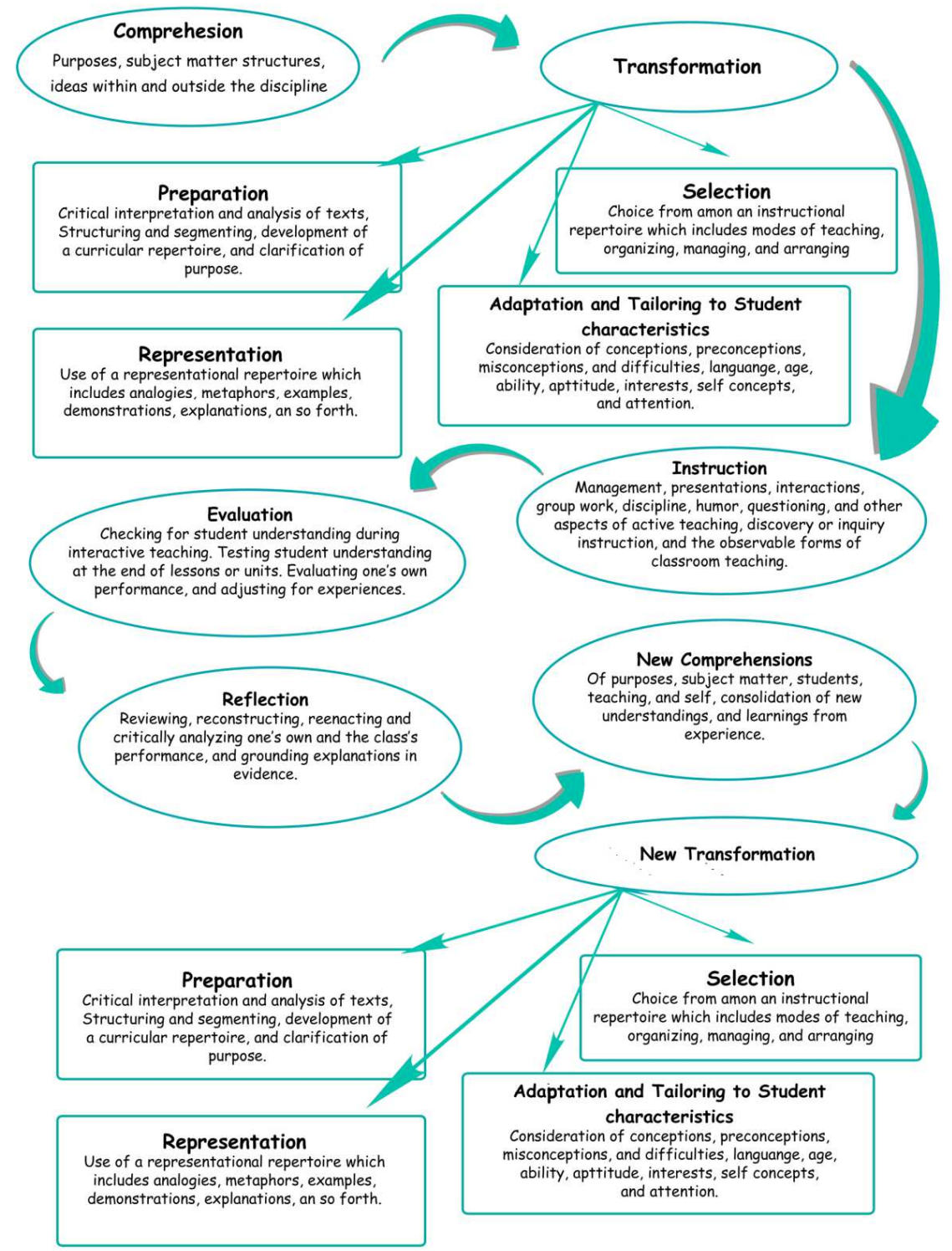

Fig 4. Model of prospective teacher knowledge 
This model was developed referring to the MPRA (Model of Pedagogical Reasoning and Action) model developed by Shulman [1] and Salazar [25]. The MPRA model developed by Shulman represents the steps that occur in the development of teacher professional practice, especially using certain content. The MPRA model begins and ends with understanding. The knowledge model for prospective teacher-students is developed beginning with understanding and ending the new transformation by prospective teacher students. The new transformations knowledge required by student-teacher candidates as a form of understanding beyond the teacher candidate knowledge gained from the learning content that follows. Through learning, student-teacher candidates are expected to be able to obtain the substance of their knowledge that is fulfilled at the new comprehension step. Furthermore, students are able to demonstrate the ability to transform their understanding in the new transformation step as a form of understanding of the substance of the material being studied.

\section{Conclusion}

The conclusions in this article include: 1) The process of forming good teachers must be prepared from the education process of prospective teachers. Prospective teacher's knowledge is an essential thing that teachers must have to be able to teach effectively. 2) Subject Matter Knowledge is needed by a teacher as a condition of mastery of the material to be taught to students. 3) learning models that can improve the professionalism of prospective teacher students, namely the AJARI Model, the AJARI learning model is a learning model that has natural characteristics, describes / articulates, reflects and my ideas. In this learning model students are expected to experience the experience of a scientist at the same time get the opportunity to design learning according to their creative ideas. Through this learning model it is expected to be a unique learning model for prospective teacher students.

\section{References}

[1] Shulman L. S. Knowledge and Teaching: Foundations of the New Reform. Harvard Educational Review. Vol. 57 (1) 1-21 (1987).

[2] Shulman L. S. Those Who Understand: Knowledge Growth in Teaching. Educational Reseacher. Vol. 15 (2) 4-14 (1986).

[3] Ball D. L. \& McDiarmid G. W., The Subject Matter Preparation of Teachers, Handbook for Research on Teacher Education. New York: Macmillan (2000)

[4] Ball, D., Thames, M. H., \& Phelps, G. Content Knowledge For Teaching. Journal of Teacher Education, 59(5), 389-407 (2008).

[5] Brousseau, G. Theory of didactical situations in mathematics: didactique des mathématiques, 1970-1990, Kluwer Academic, Dordrecht (1998).

[6] Peraturan Menteri Riset dan Teknologi No. 55 Tahun 2017 tentang Standar Pendidikan Guru.

[7] Peraturan Pemerintah No. 74 Tahun 2008 tentang Kompetensi Guru.

[8] Stecher B. M (ed). Improving Teaching Effectiveness. RAND Corporation, American Institute for Research (2018).

[9] Smith D. S. \& Daniel C. Neale. The Instruction of Subject Matter Knowledge in Primary Science Teaching, Teaching \& Teacher Education, Vol. 5 (1) pp. 1-20 (1989) 
[10] Luera, G. R., Moyer, R. H., \& Everett, S. A. What type and level of science content knowledge of elementary education students affect their ability to construct an inquirybased science lesson? Journal of Elementary Science Education, 17(1), 12-25. doi:10.1007/bf03174670 (2005).

[11] Rollnick, M. And Elisabeth Mafhunga. The pace of Subject Matter Knowledge in Teacher Education IN John Loughran and Marylynn Hamilton (Eds). The International Handbook on Teacher Education Dordrecht: Spinger, 423-452 (2006).

[12] Chevallard, Y. L'analyse des pratiques enseignantes en théorie anthropologique du didactique. Recherches en Didactique des Mathématiques, 19(2), 221-266 (1999)

[13] Carlsen W. S. Teacher Knowledge and Discourse Control: Quantitative Evidence From Novice Biology Teachers' Classroom, Journal of Research in Science Teaching. Vol. 30 (5) 471-481 (1993).

[14] Ding, L. et al. Relations between Subject Matter Knowledge and Pedagogical Content Knowledge: A Study of Chinese Pre-Service Teachers on the Topic of Three-Term Ratio. The Mathematics Educator. Vol. 15 p. 50-76 (2014)

[15] Grossman, P. L. The making of a teacher: Teacher knowledge and teacher education. New York, NY: Teachers College Press (1990).

[16] Schwab, J.J. Science, Curriculum and Liberal Education. Chicago: University of Chicago Press (1978).

[17] Dewey, J. The supreme intellectual obligation. Science, 79(2046), 240-243. (1934)

[18] Hurd, P. D. Scientific literacy: New minds for a changing world. Science education, 82(3), 407-416 (1998)

[19] Organisation for Economic Co-operation and Development (OECD) Database: PISA (2006)

[20] Ozden M. The Effect of Content Knowledge on Pedagogical Content Knowledge: The Case of Teaching Phases of Matters,. Education Sciences: Theory \& Practice, 8 (2), 633645 (2008)

[21] Grauer, K. Walking the talk: the challenge of pedagogical content in art teacher education. Readings in canadian art teacher education, 73-80. (1997).

[22] Beeby, C. Quality of Education in Developing Countries, Cambridge, MA: Harvard Academic Press (1966).

[23] Richey, R. C., \& Klein, J. D. Developmental research methods: Creating knowledge from instructional design and development practice. Journal of Computing in higher Education, 16(2), 23-38 (2005).

[24] Prawiradilaga, D. S. Prinsip desain pembelajaran. Kencana (2015).

[25] Salazar, S. F. El conocimiento pedagógico del contenido como categoría de estudio de la formación docente. Actualidades investigativas en educación, 5(2) (2005). 
